\title{
Household food security, anthropometric assessment of nutritional status and socioeconomic status of families in an urban community
}

\section{Nivel de seguridad alimentaria, estado nutricional antropométrico y condiciones socioeconómicas de familias de una comunidad urbana}

\author{
iD ${ }^{1,2}$ Jose Alvaro Niño Medina (iD ' 1 Angela Mariana Molina Pérez (iD 'Luis Ernesto Muñoz Rodríguez \\ iD ${ }^{1,2}$ Ana Karina Ortega Toro iD ${ }^{1,3}$ Nayka Diaz Wever
}

Health Sciences Faculty. University of Carabobo. Venezuela'

Law and Political Sciences Faculty. University of Carabobo. Venezuela. ${ }^{2}$

Nutrition Research Institute (INVESNUT, by its Spanish acronym). Health Science Faculty. University of Carabobo. Venezuela ${ }^{3}$

Recibido: Junio 2020

Aceptado:

Agosto 2020

\begin{abstract}
Insufficient food production and low incomes are common problems in developing countries, thus perpetuating malnutrition and poverty conditions; establishing food security as an indicator of great impact to estimate the quality of life of families. The objective of this study was to assess the level of food security, nutritional status and socioeconomic status of families in an urban community. 155 families from an urban community of Naguanagua, Carabobo state, Venezuela were evaluated during the months August-September 2018. An ad hoc clinical history was designed, the Household Food Insecurity (FI) Scale was applied, the nutritional status was assessed by body mass index (BMI), mid-upper arm circumference (MUAC) and waist-to-height ratio (WHtR); as well as the socioeconomic status (Graffar-Méndez Castellano and the Poverty Threshold). $58.1 \%$ of families presented mild FI. $19.5 \%$ of the pediatric group presented malnutrition, while in adults, overweight and obesity stood out (44.1\%); $62.5 \%$ presented cardio-metabolic risk for WHtR; $16.4 \%$ exhibited low protein reserves and $92.9 \%$ of the families were in extreme poverty. Food security was significantly correlated with $\mathrm{BMI}, \mathrm{WHtR}$, weight loss, and income. In conclusion, almost the entire sample was found in $\mathrm{Fl}$ and in extreme poverty.
\end{abstract}

Keywords: Food security, nutritional status, anthropometry, socioeconomic status.

\section{Resumen}

La producción insuficiente de alimentos y los bajos ingresos son problemas comunes en los países en vías de desarrollo, perpetuando, de esta forma, la malnutrición 
y las condiciones de pobreza; de allí que la seguridad alimentaria se considere un indicador de gran impacto para estimar la calidad de vida de las familias. El objetivo de este estudio fue evaluar el nivel de seguridad alimentaria, estado nutricional antropométrico y condiciones socioeconómicas en familias de una comunidad urbana. Se evaluaron 155 familias de una comunidad urbana de Naguanagua, estado Carabobo, Venezuela durante los meses agosto-septiembre de 2018. Se diseñó una historia clínica ad hoc, se aplicó la Escala de Inseguridad Alimentaria (IA) percibida en el hogar, se determinó el estado nutricional antropométrico por índice de masa corporal (IMC), circunferencia de brazo (CB) e índice cintura/talla (ICT); así como las condiciones socio-económicas (Graffar-Méndez Castellano y Línea de Pobreza). El 58,1 \% de las familias presentaron IA leve. El 19,5\% del grupo pediátrico presentó desnutrición, mientras que en adultos destacó el sobrepeso y la obesidad (44,1 \%); 62,5 \% presentó riesgo cardio-metabólico por ICT; 16,4 \% tenían bajas reservas proteicas y $92,9 \%$ de las familias se encontraron en pobreza extrema. La seguridad alimentaria se correlacionó significativamente con IMC, ICT, pérdida de peso e ingreso. En conclusión, casi la totalidad de la muestra se encontró en IA y en pobreza extrema.

Palabras clave: Seguridad alimentaria, estado nutricional, antropometría, condiciones socio-económicas.

\section{INTRODUCTION}

All human beings have the right to an adequate standard of living, including adequate food, as well as the fundamental right to live a life free from hunger. For this reason, in September 2015, the Member States of the United Nations (UN) approved the 2030 Agenda, which encompasses a set of Sustainable Development Goals (SDGs) that includes ending hunger, achieving food security and improved nutrition, and promoting sustainable agriculture (Economic Commission for Latin America and the Caribbean [ECLAC], 2018).

In Venezuela, food security is enshrined in the National Constitution, article 305 (1999) and the Organic Law for Food Security and Sovereignty (LOSSA, by its Spanish acronym), article 8 (2008), where it is indicated the right to availability and timely access to enough quality food. However, such a right has become a fable and its guarantee is short-lived. The decline of purchasing power and food scarcity due to the devastating effects of inflation and shortages have made it increasingly difficult to consume essential foods.

In this regard, food security is defined as the moment when all people, at all times, have physical, social and economic access to sufficient, safe and nutritious food which meets their dietary needs and food preferences for an active and healthy life. This concept embraces four fundamental dimensions: physical availability, economic and physical access, and food utilization, as well as the stability of the previous three dimensions over time; so that, for food security objectives to be realized, all four dimensions must be fulfilled simultaneously, therefore, if there is any alteration in them, there is talk of food insecurity (FI) (European Community-Food and Agriculture Organization of the United Nations [ECFAO], 2011).

During the year of 2018, the Global Report on Food Crises recognized the need to monitor Venezuela, since it is classified within the countries with $\mathrm{Fl}$, as a result of the lack of updated data and the discrepancies observed by the different institutions at national level (FAO, World Food Programme [WFP] \& International Food Policy Research Institute [IFPRI], 2018).

According to this, the National Institute of Statistics of Venezuela (INE, by its Spanish 
acronym, 2016), for the year of 2015, reported that the intake of three meals a day had $52.7 \%$. Nonetheless, for that same year, the Survey of Standards of Living (ENCOVI, by its Spanish acronym) reported that $12.1 \%$ of the sample consumed a number of two or fewer meals a day. Likewise, $87 \%$ expressed that the income was not enough to buy food, manifesting $\mathrm{Fl}$ as a result of poverty and as a cause of malnutrition (Landaeta-Jiménez, M., Herrera, M., Ramírez, G. \& Vásquez, M., 2015).

Consequently, the relationship between food security, nutritional status and socioeconomic status seems to be undeniable, since the high cost of nutritious food, the stress of living with $\mathrm{Fl}$; as well as physiological adaptations to food restriction, help explain the connection between these phenomena, so that an individual who has insufficient income to obtain the basic products for daily consumption; coupled with a marked shortage, would cause serious nutritional issue in the members of each household.

From there, the objective of this study was to assess the level of food security, nutritional status and socioeconomic status of families in an urban community.

\section{METHODS}

\section{Research design and study population}

It is about a descriptive, correlational, non-experimental and cross-sectional research. The population consisted of 204 households belonging to the El Cafetal neighborhood, Naguanagua municipality, Carabobo state, Venezuela. The sample was 144 households, equivalent to 155 families ( $\mathrm{n}: 445$ subjects), since there were households with two or more families. For statistical purposes, it was classified into two age groups: subjects from 5 to 19 years of age ( $n$ : 82 ) and over 20 years of age ( $n$ : 363$)$, of both sexes and apparently healthy.

\section{Data collection and ethical considerations} Data collection was carried out during the months August-September 2018, through interviews and their respective anthropometric assessments of nutritional status. An ad hoc clinical history was designed, made up of identification and demographics (name, sex and age) anthropometric variables and monthly family income. According to the bioethical principles and the involvement of children and adolescents in this work, each head of the family was informed about the objectives, benefits and possible risks of their participation through informed consent, following the ethics in human research.

\section{Household food security}

The level of food security was estimated by means of the Household Food Insecurity Scale, and consists of 12 questions which refer to situations regarding food that people face during a period of time in homes, in this case during the last six months. The response categories are: never (0 points), sometimes (1 point), frequently ( 2 points) or always (3 points). This scale considers a family with food security when 0 points are obtained; mild Fl: between 1 and 12 points; moderate Fl: between 13 to 24 points and severe Fl: $\geq 25$ points (Mercado \& Lorenzana, 2000).

\section{Anthropometric assessment of nutritional status}

All the study participants underwent the following anthropometric measurements: weight, height, mid-upper arm circumference (MUAC) and waist circumference (WC), according to the manual of anthropometric procedures and techniques of the Nutritional Assessment Laboratory of the Simon Bolivar University, using a previously calibrated balance for weight determination and a non-extendable measuring tape for height, MUAC and WC as instruments (Herrera, Pérez, Hernández, Hernández \& Suárez, 2010).

For the nutritional diagnosis in the individuals between 5 and 19 years of age, the heightfor-age index was constructed and, likewise, the body mass index (BMI) (weight/height ${ }^{2}$ ) $\left(\mathrm{Kg} / \mathrm{m}^{2}\right)$ was calculated for the BMl-for-age 
Z-score to be used. The results were classified according to reference values of the World Health Organization (WHO, 2007). For adults, BMI was calculated and WHO's reference values were used (WHO, 2000).

For the determination of the MUAC, the reference values established by Frisancho (1993) were used, with the exception of adults over 75 years of age, which were not included, because these tables do not report percentile values. The waist-to-height ratio ( $\mathrm{WHtR}$ ) was calculated with the values obtained for height and WC, considering the cutoff of 0.5 as an indicator of abdominal obesity and cardio-metabolic risk (Ashwell \& Hsieh, 2005).

\section{Socioeconomic status and poverty threshold}

Socioeconomic status was determined using the Graffar-Méndez Castellano and the Poverty Threshold (PT) methods. The first evaluates the profession of the head of the family, the mother's educational level, source of family income, as well as housing quality. Each variable is given a score and the sum total places the family: from 4 to 6 points for stratum I (upper class), from 7 to 9 stratum II (upper-middle class), from 10 to 12 stratum III (lover-middle class), from 13 to 16 stratum IV (working class) and $\geq$ to 17 stratum $V$ (lower class) (Benítez \& Dunia, 2011).

For its part, the PT assesses the monetary cost of a reference welfare level for a family, at a given time and place, for which two essential variables were used: household income and the market basket (ECLAC, 2000). Thus, for this method, poverty is that which is given by the per capita income of households; if it is less than the cost of the market basket, they were referred as poor people, whereas, if it is less than estimated price of the basic food basket, they were reported as extremely poor individuals (INE, n.d.).

\section{Statistical analysis}

The data was processed by the SPSS statistical program version 16.0. Descriptive statistics were performed. The distribution of the normality of the variables was verified according to the Kolmogorov-Smirnov test. Kruskal-WaIlis was used to compare the averages and Spearman's rank correlation coefficient for the correlation of the variables. A p-value less than $0.05(p<0.05)$ was defined as statistically significant.

\section{RESULTS}

\section{Demographic characteristics}

The sample of this investigation was made up of 445 subjects of both sexes, of whom 82 were between 5 and 19 years old and 363 over 20 years of age, forming 155 families. The average age among subjects 5 and 19 years old was 11.4 with a standard deviation (SD) of 4.5 years; while, in those over 20 years of age, it was 51.9 and 18.4 years of SD (data not shown in tables).

\section{Household food security}

According to the Household Food Insecurity Scale, it was found that $58.1 \%$ of the families presented mild Fl (Figure 1).

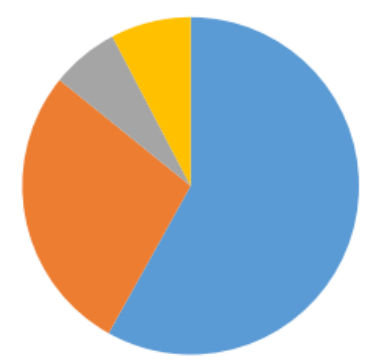

\author{
- Mild FI (58.1\%) \\ Moderate FI $(27.7 \%)$ \\ Severe FI $(6.5 \%)$ \\ Food Security $(7.7 \%)$
}

Figura 1. Prevalence of Food Security according to the Household Food Insecurity. Fl: food insecurity 
Anthropometric assessment of nutritional status

The BMI and MUAC decreased as FI increased, while the variable weight loss increased as grea- ter FI was found. Furthermore, there was a significant difference between BMI, WHtR and weight loss with the estimation of the level of food security (Table 1).

\section{Tabla 1}

Variables of the sample studied according to the Food Security level

\begin{tabular}{|c|c|c|c|c|c|c|c|c|c|}
\hline \multirow{3}{*}{ Variables } & \multicolumn{9}{|c|}{ Food Security Level } \\
\hline & \multicolumn{2}{|c|}{ Food Security } & \multicolumn{2}{|c|}{ Mild FI } & \multicolumn{2}{|c|}{ Moderate FI } & \multicolumn{2}{|c|}{ Severe FI } & \multirow[b]{2}{*}{$\mathrm{p}$} \\
\hline & $\mathrm{X}$ & $\mathrm{SD}$ & $\mathrm{X}$ & SD & $\mathrm{X}$ & $\mathrm{SD}$ & $\mathrm{X}$ & $\mathrm{SD}$ & \\
\hline $\operatorname{BMI}\left(\mathrm{kg} / \mathrm{m}^{2}\right)^{*}$ & 26.2 & 3.6 & 26.2 & 4.8 & 24.1 & 4.8 & 23.1 & 5.3 & 0.03 \\
\hline MUAC (cm) & 31.7 & 3.8 & 31.5 & 4.4 & 30.1 & 4.4 & 28.4 & 3.6 & 0.12 \\
\hline $\mathrm{WHtR}^{*}$ & 0.5 & 0.06 & 0.56 & 0.07 & 0.50 & 0.08 & 0.50 & 0.08 & 0.01 \\
\hline Weight loss* & 1.75 & 3.2 & 4.1 & 4.2 & 6.1 & 5.7 & 10.6 & 8.4 & 0.01 \\
\hline
\end{tabular}

When evaluating the group of subjects from 5 to 19 years of age (n: 82), it was found that for the height-for-age index, 1.2\% were in the 3rd percentile (Table 2).

\section{Tabla 2}

Frequency distribution of height-for-age index for the 5 to 19-year-old individuals (n: 82).

\begin{tabular}{ccc}
\hline Percentils & $\mathrm{n}$ & $\%$ \\
\hline 3rd & 1 & 1.2 \\
15 th & 19 & 23.2 \\
50 th & 59 & 72.0 \\
85th & 3 & 3.6 \\
Total & 82 & 100.00 \\
\hline
\end{tabular}

For the BMI-for-age Z-score index in the age group from 5 to 19 years old, 2.4\% were reported to be in severe thinness, $19.5 \%$ in thinness, $65.9 \%$ in normal range and $12.2 \%$ in overweight (Table 3).

\section{Tabla 3}

Frequency distribution of BMI-for-age Z-score for the 5 to 19-year-old individuals (n: 82).

\begin{tabular}{ccc}
\hline Classification & $\mathbf{n}$ & \% \\
\hline Severe thinness & 2 & 2.4 \\
Thinness & 16 & 19.5 \\
Normal range & 54 & 65.9 \\
Overweight & 10 & 12.2 \\
\hline Total & 82 & 100 \\
\hline
\end{tabular}


In regard to MUAC in children, $18.3 \%$ exhibited low protein reserves (Table 4).

\section{Tabla 4}

Frequency distribution of protein reserves by MUAC for the 5 to 19-year-old individuals ( $\mathbf{n}: \mathbf{8 2}$ ).

\begin{tabular}{ccc}
\hline Classification & $\mathbf{n}$ & $\mathbf{\%}$ \\
\hline Low protein reserves & 15 & 18.3 \\
Adequate protein reserves & 65 & 79.3 \\
High protein reserves & 2 & 2.4 \\
\hline Total & 82 & 100 \\
\hline
\end{tabular}

In the group over 20 years of age, it was observed that $9.1 \%$ presented underweight,
46.8\% were in normal range and $44.1 \%$ had overweight or obesity for the BMI (Table 5).

\section{Tabla 5}

Frequency distribution of BMI for the 20-year-old individuals (n: 363 ).

\begin{tabular}{ccc}
\hline Classification & $\mathbf{n}$ & $\mathbf{\%}$ \\
\hline Underweight & 33 & 9.1 \\
Normal range & 170 & 46.8 \\
Overweight & 105 & 28.9 \\
Obesity & 55 & 15.2 \\
\hline Total & 363 & 100 \\
\hline
\end{tabular}

In addition to that, in adults, it was observed that $62.5 \%$ presented cardio-metabolic risk for WHtR. In addition, $16.4 \%$ exhibited low protein reserves, $73.1 \%$ adequate protein reserves and $10.5 \%$ high protein reserves through MUAC (data not shown in tables).

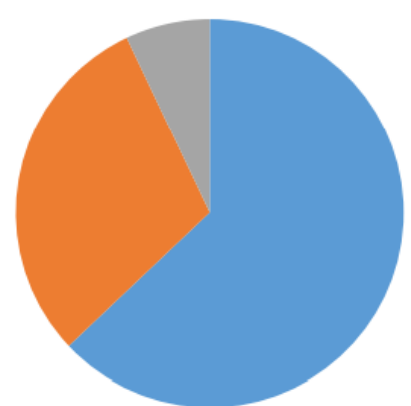

Socioeconomic status and poverty threshold

Respecting socioeconomic status, according to the Graffar-Méndez Castellano method, $58 \%$ of the sample belonged to stratum II (Figure 2).
" Stratum II (58\%)

- Stratum III (36.8\%)

- Stratum IV (5.2\%)

Figura 2. Frequency distribution of the socioeconomic status according to the Graffar-Méndez Castellano method (n: 155). 
The vast majority of families were in extreme poverty (92.9\%) according to PT, $6.5 \%$ nonpoor and $0.6 \%$ poor (data not shown in tables).

\section{Correlation between variables}

In Table 6, when correlating the variables, it was observed that food security level was significantly correlated with WHtR and weight loss in a weak and positive way, while income and BMI were also weakly correlated, but negatively. MUAC was moderately and positively correlated with $\mathrm{BMI}$ and weak and inversely correlated with $\mathrm{WH} \mathrm{tR}$. There was a moderate and inverse correlation between WHtR and BMI, whereas the latter was weakly and positively correlated with income and weakly but negatively with weight loss. The socioeconomic status according to the Graffar-Méndez Castellano was not correlated with food security, nor with anthropometric variables.

\section{Tabla 6}

Correlation between the variables studied.

\begin{tabular}{|c|c|c|c|c|c|c|c|c|}
\hline & & $\begin{array}{c}\text { Food } \\
\text { Security } \\
\text { Level }\end{array}$ & SES & MUAC & WHtR & BMI & Income & $\begin{array}{c}\text { Weight } \\
\text { loss }\end{array}$ \\
\hline \multirow{2}{*}{$\begin{array}{c}\text { Food } \\
\text { Security } \\
\text { Level }\end{array}$} & $\mathrm{p}$ & & 0.046 & -0.165 & $0.237^{*}$ & $-0.256^{*}$ & $-0.344^{*}$ & $0.350^{*}$ \\
\hline & $\mathrm{r}$ & & 0.573 & 0.052 & 0.003 & 0.001 & 0.000 & 0.000 \\
\hline \multirow{2}{*}{ SES } & $\mathrm{p}$ & 0.046 & & -0.019 & 0.017 & -0.017 & -0.071 & 0.066 \\
\hline & $\mathrm{r}$ & 0.573 & & 0.821 & 0.834 & 0.837 & 0.382 & 0.413 \\
\hline \multirow{2}{*}{ MUAC } & $\mathrm{p}$ & -0.165 & -0.019 & & $-0.431^{*}$ & $0.566^{*}$ & 0.143 & -0.060 \\
\hline & $\mathrm{r}$ & 0.052 & 0.821 & & 0.000 & 0.000 & 0.093 & 0.480 \\
\hline \multirow{2}{*}{ WHtR } & $\mathrm{p}$ & $0.237^{*}$ & 0.017 & $-0.431^{*}$ & & $-0.593^{*}$ & -0.084 & 0.152 \\
\hline & $\mathrm{r}$ & 0.003 & 0.834 & 0.000 & & 0.000 & 0.297 & 0.059 \\
\hline \multirow{2}{*}{ BMI } & $\mathrm{p}$ & $-0.256^{*}$ & -0.017 & $0.566^{*}$ & $-0.593^{*}$ & & $0.291^{*}$ & $-0.226^{*}$ \\
\hline & $\mathrm{r}$ & 0.001 & 0.837 & 0.000 & 0.000 & & 0.000 & 0.005 \\
\hline \multirow{2}{*}{ Income } & $\mathrm{p}$ & $-0.344^{*}$ & -0.071 & 0.143 & -0.084 & $0.291^{*}$ & & -0.102 \\
\hline & $\mathrm{r}$ & 0.000 & 0.382 & 0.093 & 0.297 & 0.000 & & 0.207 \\
\hline \multirow{2}{*}{ Weight loss } & $\mathrm{p}$ & $0.350^{*}$ & 0.066 & -0.060 & 0.152 & $-0.226^{*}$ & -0.102 & \\
\hline & $r$ & 0.000 & 0.413 & 0.480 & 0.059 & 0.005 & 0.207 & \\
\hline
\end{tabular}

\section{DISCUSSION}

In this study, it was observed that the evaluated urban community, in almost its entirety, presented some degree of $\mathrm{Fl}$, results that are similar to those reported by Weigel, Rodrigo, Armijos, Racines, Cevallos \& Castro (2016), in Ecuador, where it was revealed a high prevalence of Fl; however, it differs from the results shown by Jomaa, Naja, Cheaib \& Hwalla (2017) and Kim \& Oh (2015) where FI only occurred in half of Lebanese households and less than $25 \%$ of Korean households, respectively.

As a result, the inequalities that exist between the different countries seems to be evident, 
as a consequence of a possible deficit in the public-policy management related to community nutrition, specifically reflected in developing countries. Therefore, given these results, it does not seem unreasonable to suggest that, since such elevated levels of FI exist in an urban community in one of the main cities of Venezuela, it is likely that there are equal levels of $\mathrm{Fl}$, or even higher, in other centers, both rural and urban, where poverty rates and difficult access to food are estimated to be even higher.

When characterizing the nutritional status of the sample, for the group of 5 to 19 years of age, it was reported that more than 25\% presented some degree of malnutrition, mostly due to underweight. Findings that are comparable with those reported by Bergel, Oyhenart, Quintero, Navazo, Cesani \& Gazarra (2018), in Argentina, where malnutrition presented a significant prevalence, but, mostly owing to overweight and obesity.

Analyzing the height-for-age index, a minority ranked low height-for-age (3rd percentile); in a similar fashion, for Bergel et al. (2018), this prevalence was equally low, whose measurement suggests stunted growth, as a reflect of a failure to reach linear growth potential as a result of suboptimal health and/or nutritional conditions.

In spite of that, in the group of people over 20 years of age, it was found that both forms of malnutrition coexisted and dominated over the normal range, with overweight and obesity being found in a greater proportion than underweight, similar to the results obtained in a research in Bolivia, where malnutrition due to deficits occurred in less quantity than owing to excess, although both prevailed over the normal range (Soto, 2018).

This phenomenon could be supported by the fact that when household food resources begin to become scarce, people tend to choose less expensive foods that are often high in calorie density and low in nutrient content, resulting in a link between $\mathrm{Fl}$ and overweight and obesity that is no longer a paradox. In addition to that, the relationship between $\mathrm{Fl}$ and underweight is easier to comprehend; which arises from a diet characterized by an insufficient intake of calories, proteins, vitamins and minerals that prevents people's growth and development. Thereby, $\mathrm{Fl}$ is conceived to coexist with both forms of malnutrition (FAO, International Fund for Agricultural Development [IFAD], United Nations Children's Fund [UNICEF], WFP \& WHO, 2018).

On the other hand, assessing the MUAC, it was determined that more than $10 \%$ of the sample exhibited low protein reserves. This could be related to the low consumption of protein in food, since for 2016, according to estimates made in Venezuela, the main foods for consumption were flours, vegetables and tubers, displacing animal proteins, such as chicken and meat (Landaeta-Jiménez, M., Herrera, M., Ramírez, G. \& Vásquez, M., 2016).

WHtR has proven to be a strong indicator, not only for abdominal obesity, but also as a predictor of risk factors for cardiovascular disease. Thus, in the present study, more than half of the sample presented cardio-metabolic risk. This could be associated with $\mathrm{Fl}$, where the limited availability or difficult access to food generates changes in the pattern of purchase and consumption, with fats and carbohydrates prevailing in families, causing an excessive accumulation of body fat (Matsuzawa, 2010).

When establishing the socioeconomic status of the community, it was observed that the majority belonged to an upper-middle stratum, without showing any correlation with any variable, unlike the research made by Haro-Mota, Marceleño-Flores, Bojórquez-Serrano \& Nájera-González (2016) where the highest prevalence of Fl had a high correlation with the low level of education of the head of the family. Consequently, it can be inferred that the socioeconomic status determined by 
the Graffar-Méndez Castellano method does not correspond to the quality of life in the evaluated sample.

Regarding the level of poverty, almost all of the families evaluated were found to be in extreme poverty, in contrast to the ENCOVI (Spain \& Ponce, 2018) where only slightly more than half of their sample were extremely poor. This could be a result of a collapse of the Venezuelan economy with the decrease in the price of oil and the reduction in the income obtained from it, which determined that, in a hyperinflationary context such as the one currently suffered by Venezuela, all households are below an unreachable PT, so that it no longer segments the population and does not reflect the phenomenon (Spain \& Ponce, 2018; FAO, IFAD, WHO, WFP \& UNI(EF, 2017).

Food security was correlated weakly and positively with $\mathrm{WHtR}$ and weight loss, whereas income and BMI were also weakly correlated with food security, but negatively. This phenomenon could be expression of a country, such as Venezuela, where there are non-indexed wages and lagged increases in the formal sector, which favor impoverishment due to the inflation, and, therefore, a greater difficulty in acquiring essential food. Consequently, Venezuelans face multiple obstacles: there is no food to be found, the little that can be found has gone up in price so much that it cannot be bought, and for the little that money can achieve, it is not quality-worthy.

Along these lines, it is not difficult to conceive that the lower the income, the higher the Fl and, thereupon, the greater the cardio-metabolic risk and weight loss, since it is increasingly difficult to access nutritious food, causing a serious impact on an adequate standard of living and health, affecting not only the most vulnerable groups, but also the middle and upper classes.

On the other hand, the MUAC was weakly and inversely correlated with the WHtR, ma- king it paradoxical to think that a person with an increased WC to height and, consequently, with cardio-metabolic risk, coexists with a decreased MUAC; however, in a social and economic context such as that experienced by Venezuelans, it could be inferred that there is a serious distortion in dietary intake that is characterized by insufficient intake of protein and vitamins, but rich in calorie-dense foods that constitute an obesogenic factor, since nutritious and fresh foods tend to be more expensive.

\section{CONCLUSIONS}

-Almost the entire sample was found in Fl. Likewise, malnutrition, due to deficit and excess, and WHtR as a predictor of cardio-metabolic risk were high. Assessing MUAC, it was inversely correlated with $\mathrm{WH} t \mathrm{R}$, as a possible result of a diet lacking in essential nutrients.

-The socioeconomic status in the studied sample was not correlated with any variable, so the Graffar-Méndez Castellano method is no longer useful as a tool to determine the quality of life for these families.

-Most of the subjects evaluated were poor by PT, where extreme poverty was the result of insufficient salary for the acquisition of the food basket.

\section{BIBLIOGRAPHIC REFERENCES}

Ashwell, M.\&Hsieh, S. D. (2005). Six reasons why the waist-to-height ratio is a rapid and effective global indicator for health risks of obesity and how its use could simplify the international public health message on obesity. International Journal of Food Sciences and Nutrition, 56(5), 303-307. Retrieved January 2020 from: https://doi.org/10.1080/09637480500195066

Benítez M. \& Dunia M. (2011). Evaluación del método de estratificación social Graffar-Méndez Castellano. [Dissertation of Bachelor]. Universidad Católica Andrés Bello. Facultad de Ciencias Económicas y Sociales. Caracas, Venezuela. 
Bergel, M., Quintero, F., Navazo, B., Cesani, M., Garraza, M., Torres, M., Luna, M., Luis, M., Castro, L. \& Oyhenart, E. (2016). Caracterización del estado nutricional en relación con factores socio-ambientales de la población escolar del Partido de Punta Indio (Provincia de Buenos Aires, Argentina). Revista Argentina de Antropología Biológica, 18(2),1-13. Retrieved February 2020 from: https://www.redalyc.org/articulo. oa? id $=3822 / 382245796010$

Constitución de la República Bolivariana de Venezuela. (1999). Caracas: Asamblea Nacional Constituyente. Retrieved February 2020 from: https://www.oas.org/dil/esp/constitucion_venezuela.pdf

EC-FAO. (2011). Una introducción a los conceptos básicos de la seguridad alimentaria. La Seguridad Alimentaria: Información para la toma de decisiones. Guía Práctica. Retrieved January 2020 from: http://www.fao.org/ docrep/014/al936s/al936s00.pdf

ECLAC. (2018). Agenda 2030 y los Objetivos de Desarrollo Sostenible Una oportunidad para América Latina y el Caribe. 1era Ed. Santiago de Chile. Retrieved February 2020 from: https://repositorio.cepal.org/bitstream/handle/11362/40155/24/S1801141_es.pdf

ECLAC. (2000). La medición de la pobreza: El método de las líneas de pobreza. $4^{\circ}$ taller regional. Buenos Aires, Argentina. Retrieved February 2020 from: https://repositorio. cepal.org/bitstream/handle/11362/31427/ S2000704_es.pdf? sequence $=1$ \&isAllowed $=y$

España L. \& Ponce M. (2018). Encuesta sobre Condiciones de Vida en Venezuela. (ENCOVI). Caracas: Dirección de Servicios multimedia de la Universidad Simón Bolívar. Retrieved January 2020 from: https://encovi.ucab.edu. ve/wp-content/uploads/sites/2/2018/02/ ucv-ucab-usb-encovi-pobreza-2017.pdf

FAO, IFAD, OMS, WFP \& UNICEF. (2017). El estado de la seguridad alimentaria y la nutrición en el mundo 2017. Fomentando la resiliencia en aras de la paz y la seguridad alimentaria. Roma: FAO. Retrieved January 2020 from: http://www.fao.org/3/a-l7695s.pdf

FAO, IFAD, UNICEF, WFP y OMS. (2018). El estado de la seguridad alimentaria y la nutrición en el mundo. Fomentando la resiliencia climática en aras de la seguridad alimentaria y la nutrición. 1era ed. Roma, Italia: FAO. Retrieved January 2020 from: http://www.fao. org/3/l9553ES/i9553es.pdf

FAO, WFP \& IFPRI. Informe Mundial sobre Crisis Alimentarias. (2018) Roma: Food Security Information Network. Retrieved February 2020 from: https://www.wfp.org/content/ global-report-food-crises-2018

Frisancho, AR. (1993). Anthropometric standards for the assessment of growth and nutritional status. The University of Michigan Press: Ann Arbor.

Haro-Mota, R., Marceleño-Flores, S., Bojórquez-Serrano, J. \& Nájera-González, O. (2016). La inseguridad alimentaria en el estado de Nayarit, México, y su asociación con factores socioeconómicos. Salud Pública de México, 58(4), 421-427. Retrieved February 2020 from: https:// dx.doi.org/10.21149/spm.v58i4.8022

Herrera, H., Pérez, A., Hernández, A., Hernández de V, Y., y Suárez, S. (2010). Antropometría nutricional y composición corporal en adultos. Manual de uso para la práctica clínica. Laboratorio de Evaluación Nutricional/Unidad de Nutrición y Alimentación. Universidad Simón Bolívar, Caracas.

INE. (2016) Encuesta Nacional de Consumo de Alimentos (ENCA). Caracas, Venezuela. Retrieved February 2020 from: http://www.ine. gov.ve/documentos/Social/ConsumodeAlimentos/pdf/informe_enca.pdf

INE. (n.d.). Caracas, Venezuela. Instituto Nacional de Estadística. Retrieved February 2020 
from: http://www.ine.gob.ve/index. php?option=com_content\&id=336\&ltemid $=45 \&$ view $=$ article $\% 20 \% 20 \% 20 \% 20$

Jomaa, L., Naja, F., Cheaib, R. \& Hwalla, N. (2017). Household food insecurity is associated with a higher burden of obesity and risk of dietary inadequacies among mothers in Beirut, Lebanon. BMC Public Health, 17(1), 567. Retrieved February 2020 from: https://doi. org/10.1186/s12889-017-4317-5

Kim H. \& Oh K. (2015). Household food insecurity and dietary intake in Korea: results from the 2012 Korea National Health and Nutrition Examination Survey. Public Health Nutrition. 18(18):3317-3325. Retrieved February 2020 from: https://www.cambridge.org/ core/journals/public-health-nutrition/article/ household-food-insecurity-and-dietary-intake-in-korea-results-from-the-2012-korea-national-health-and-nutrition-examination-survey/ CB6AC13865A43C7922B3525356D32F75/COre-reader

Landaeta-Jiménez, M., Herrera, M., Ramírez G \& Vásquez M. (2015). Encuesta Nacional sobre Condiciones de Vida en Venezuela. UCAB, USB, UCV. Caracas, Venezuela. Retrieved February 2020 from: https://encovi.ucab.edu. ve/wp-content/uploads/sites/2/2018/02/ ucv-ucab-usb-encovi-alimentacion-2015. pdf

Landaeta-Jiménez, M., Herrera, M., Ramírez, G. \& Vásquez, M. (2016). Encuesta Nacional sobre Condiciones de Vida. UCAB, USB, UCV. Caracas, Venezuela Retrieved February 2020 from: https://www.fundacionbengoa.org/encovi/2016/ENCOVI-2016-Alimentacion.pdf

Matsuzawa, Y. (2010). Establishment of a concept of visceral fat syndrome and discovery of adiponectin. Proceedings of the Japan Academy. Series B, Physical and Biological Sciences, 86(2), 131-141. Retrieved January 2020 from: https://doi.org/10.2183/pjab.86.131
Mercado C. \& Lorenzana P. (2000). Acceso y disponibilidad alimentaria familiar, validación de instrumentos para su medición. Caracas: Fundación Polar.

Ley Orgánica de Seguridad y Soberanía Agroalimentaria (2008). Caracas: Asamblea Nacional. Retrieved January 2020 from: http:// www.fao.org/pgrfa-gpa-archive/ven/ley_soberania.pdf

Soto, J. (2018). Estudio del estado nutricional de la población de la zona de Pasankeri en la ciudad de La Paz, aplicando tecnología móvil. Fides et Ratio - Revista de Difusión Cultural y Científica de la Universidad La Salle en Bolivia, 15(15), 111-130. Retrieved February 2020 from: http://www.scielo.org.bo/scielo.php?script=sci_arttext\&pid=S2071-081X2018000100008\&lng=es\&tlng=es.

Weigel M., Rodrigo, X., Armijos, M, Cevallos, W. \& Castro, N. (2016). Association of Household Food Insecurity with the Mental and Physical Health of Low-Income Urban Ecuadorian Women with Children. Journal of Environmental and Public Health, vol. 2016, pp. 1-14, 2016. Retrieved February 2020 from: https://www. hindawi.com/journals/jeph/2016/5256084/.

WHO. (2007). BMI-for-age (5-19 years). Who.int. Retrieved January 2020 from: http://www.who. int/growthref/who2007_bmi_for_age/en/

WHO. (2007). Height-for-age (5-19 years). Who.int. Retrieved January 2020 from: http://www.who. int/growthref/who2007_height_for_age/en/

WHO. (2000). Obesity: preventing and managing the global epidemic. Report of a WHO consultation. World Health Organ Technical Report Series 894: i-xii, 1-253.

\section{CORRESPONDENCIA:}

Dra. Nayka Diaz Wever ndiazw@gmail.com 